\title{
Feed additives for swine: Fact sheets - acidifiers and antibiotics
}

Jay Y. Jacela, DVM; Joel M. DeRouchey, PhD; Mike D. Tokach, PhD; Robert D. Goodband, PhD; Jim L. Nelssen, PhD; David G. Renter, DVM, PhD; Steve S. Dritz, DVM, PhD

\section{Introduction}

Feed additives are non-nutritive products used in swine diets to improve production efficiency and performance. If chosen carefully and used properly, feed additives can be effective and can help increase the profitability of pig production. Not all feed additives are the same or provide a beneficial response and, therefore, choosing a product will depend on the farm's specific situation and needs.

This series of fact sheets includes some of the major classifications of products used as feed additives. Every effort has been made to ensure that all the information in every fact sheet is current and based on the latest scientific publications available at the time of writing. The objective of these fact sheets is to discuss some of the basic concepts to help producers improve their understanding of these products. They also aim to promote more responsible and judicious use of feed additives.

Feed-additive products used in swine diets include natural and synthetic substances and have been grouped in this series of fact sheets according to the classifications shown in the text box.

Each group of feed additives is discussed in a separate fact sheet, with special emphasis on some of the common questions that producers might have for each product. Feed additives offer a variety of potential benefits. However, they add to total production cost and should be evaluated carefully. Because their use in pig diets is to improve performance and profitability, an effective feed-additive product must be able to pay for itself. It must be able to provide an improvement in productivity that is, at minimum, equivalent to the added cost of the feed-additive product. This highlights the value of scientific data from well-designed experiments as the basis for evaluating such products. Having access to such information is critical in determining if one product's claims are actually possible and repeatable in commercial settings. Producers must always try to verify that the data for a particular product came from controlled, unbiased experiments with supporting statistical data. When choosing between feed-additive products, priority for using a specific product should be given to those that have been shown to provide consistent results in research trials.

\section{Feed-additive products for swine}

Acidifiers

Anthelmintics (dewormers)

Antibiotics

Carbohydrate-degrading enzymes and proteases

Carcass modifiers

Flavors
High dietary levels of copper and zinc for growing pigs

Mold inhibitors, mycotoxin binders, and antioxidants

Phytase

Phytogenic feed additives (phytobiotics-botanicals)

Probiotics and prebiotics

\section{This begins a series of peer-reviewed Practice tip articles, each including two or three fact sheets.}

JYJ, DGR, SSD: Department of Diagnostic Medicine/Pathobiology, Kansas State University, Manhattan, Kansas.

JMD, MDT, RDG, JLN: Department of Animal Science and Industry, Kansas State University, Manhattan, Kansas.

Corresponding author: Dr Jay Y. Jacela, I-102 Mosier Hall, 1800 Denison Ave, Manhattan, KS 66506; Tel: 785-532-4845; E-mail: jjacela®vet.ksu.edu.

This article is available online at http://www.aasv.org/shap.html.

Jacela JY, DeRouchey JM, Tokach MD, et al. Feed additives for swine: Fact sheets - acidifiers and antibiotics. J Swine Health Prod. 2009;17(5):270-275. 
Beneficial claims from dietary inclusions of acidifiers include control of bacterial growth in feed, increased growth performance, improvement in nutrient digestibility, and control of harmful bacteria in the gut.

\section{What are acidifiers?}

Acidifiers are compounds that have acidic properties: they may be organic or inorganic acids. Organic acids that have shown positive effects on growth performance in weaned pigs include citric, formic, fumaric, and propionic acids. In studies involving inorganic acids, ${ }^{1-3}$ positive growth responses have been reported with the use of phosphoric acid. However, research evaluating other inorganic acids, such as sulfuric acid, reported negative growth performance. ${ }^{4}$ Thus, phosphoric acid is the most commonly utilized inorganic acid in swine diets.

Inorganic acids are usually less costly than organic acids. Organic and inorganic acid combinations are often used in commercially available acidifiers. The response to mixed acids is generally better than to single acids, ${ }^{5}$ apparently due to dissociation properties of these acids at various locations in the pig's digestive tract.

\section{What are the benefits of using acidifiers?}

A recent report ${ }^{2}$ summarizing several studies on acidifiers indicated that, in general, they appear to improve pig growth performance. However, the magnitude and consistency of the response may vary, depending on inclusion rate and other dietary factors. The exact mode of action of acidifiers has not been fully elucidated. However, acidifiers are commonly marketed as growth-promoting products and as alternatives for in-feed antibiotics. Unfortunately, due to the lack of consistent results, use of acidifiers to replace antibiotic growth promoters is still not justified. Acidifiers are believed to enhance growth by improving gut health through reduction of $\mathrm{pH}$ and buffering capacity of diets, improvement of pancreatic secretions that increase nutrient digestibility, or promotion of beneficial bacterial growth while inhibiting growth of pathogenic microbes. ${ }^{2,6}$ There is limited data indicating that acidifiers can act synergistically with phytase to improve phosphorus and magnesium digestibility. 7,8

\section{What factors affect the response to acidifiers?}

Research suggests that age of pigs can affect the response to acidifiers, with newly weaned pigs showing the greatest response. ${ }^{4,9}$ Acidifiers are most beneficial during the first few days after weaning. The stomach of a weaned pig is not yet physiologically mature and may not be able to secrete a sufficient amount of acid to aid in digestion of solid food or inhibit proliferation of detrimental bacteria. However, the exact mechanism of the response to acidifiers is not clear.

Diet composition also may affect the response to acidifiers. It appears that greater responses are seen when simple diets are fed rather than complex diets containing milk products. ${ }^{10}$ This is presumably due to conversion of lactose from the milk products to lactic acid by Lactobacillus species in the stomach, thus creating an acidic environment and reducing the need for dietary supplementation with acidifiers.

\section{Fast facts}

Acidifiers used in pig diets may be in organic or inorganic forms.

Acidifiers appear to be most effective in newly weaned pigs and in less complex nursery diets.

Growth-promoting effects of acidifiers in pig diets need to be further investigated to be justified as suitable replacements for antimicrobials.

\section{Disadvantages of acidifiers}

Corrosiveness, one disadvantage of using some acidifiers, may pose handling and equipment issues to the feed manufacturer. Salts of organic acids are generally odourless and less corrosive than their acid forms, making them easier to handle in the feed manufacturing process. Acidifiers may negatively affect diet palatability when added at excessive levels, resulting in lower feed intake. There may also be legal restrictions with the use of some acids. For example, pure formic acid is not legal for use in the United States, but salts of formic acid are available for use in feeds.

\section{Summary}

Acidifiers added to pig diets may potentially help improve growth performance by improving digestive processes through several mechanisms. However, a clear mode of action has yet to be described. The use of acidifiers appears to be most beneficial in the early period after weaning. Thus, acidifier use is typically limited to diets for pigs weighing less than $6.75 \mathrm{~kg}(15 \mathrm{lb})$.

\section{References}

1. Walsh MC, Sholly DM, Hinson RB, Saddoris KL, Sutton AL, Radcliffe JS, Odgaard R. Murphy J, Richert BT. Effects of water and diet acidification with and without antibiotics on weanling pig growth and microbial shedding. J Anim Sci. 2007;85:1799-1808.

2. Tung CM, Pettigrew JE. Critical review of acidifiers. National Pork Board. 2006. Available at: http://www.pork.org/Documents/PorkScience/ ReviewOfAcidifiers.pdf. Accessed 10 April 2009.

*3. Stein H. Feeding the pig's immune system and alternatives to antibiotics. Proc London Swine Conf. London, Ontario, Canada. 2007;65-82.

4. Ravindran V, Kornegay ET. Acidification of weaner pig diets: A review. J Sci Food Agric. 1993;62:313-322.

5. Hardy B. The issue of antibiotic use in the livestock industry. What have we learned? Anim Biotechnol. 2002;13:129-147.

6. Partanen KH, Mroz Z. Organic acids for performance enhancement in pig diets. Nutr Res Rev. 1999;12:117-145.

7. Omogbenigun FO, Nyachoti CM, Slominski BA. The effect of supplementing microbial phytase and organic acids to a corn-soybean based diet fed to early-weaned pigs. J Anim Sci. 2003;81:1806-1813.

8. Jongbloed AW, Mroz Z, van der Weij-Jongbloed R, Kemme PA. The effects of microbial phytase, organic acids and their interaction in diets for growing pigs. Livest Prod Sci. 2000;67:113-122.

9. Bergstrom JR, Nelssen JL, Tokach MD, Goodband RD, Loughmiller JA, Musser RE, Nessmith WB Jr. An evaluation of several diet acidifiers commonly used in pig starter diets to improve growth performance. Kansas Agricultural Experiment Station Progress Report 772. 1996;772:74-78. Available at: www.oznet.ksu.edu/library/lvstk2/srp?72.pdf. Accessed 15 July 2009.

10. Weeden TL, Nelssen JL, Hansen JA, Richardson KL. Effect of acidification on starter pig performance and nutrient digestibility. Kansas Agricultural Experiment Station Progress Report 610. 1990;610:62-65. Available at: www. oznet.ksu.edu/library/lvstk2/srpblØ.pdf. Accessed 15 July 2009.

* Non-refereed reference. 
Antimicrobial agents, such as antibiotics, have been used in pig production for over 50 years. Early studies indicated significant improvements in pig growth performance when antibiotics were fed. With the improvements in production practices and health status of pig herds, positive responses to in-feed antibiotics may not be as large in today's modern facilities. Additionally, the magnitude of response differs with the stage of pig growth. Use of antibiotics as feed additives is subject to regulatory policies to prevent residues and enhance public health. It is therefore important to be aware of the current information available concerning the effects of commonly used in-feed antibiotics in pig production.

\section{How do antibiotics enhance growth?}

Antibiotics are non-nutritive feed additives, which means that they do not provide further nourishment to the pig, and their absence in a well-balanced diet will not result in nutritional deficiency. Antibiotics are included in swine feed for their therapeutic potential as well as their ability to promote growth. Some of the proposed possible mechanisms by which antibiotics improve growth include inhibition of subclinical pathogenic bacterial infections; reduction of microbial metabolism products that may negatively affect pig growth; inhibition of microbial growth, thereby increasing nutrients available to the pig; and an increase in uptake and utilization of nutrients through the intestinal wall. ${ }^{1}$

\section{Efficacy of in-feed antibiotics}

Studies $^{2}$ on the effects of antibiotic feed additives have indicated significant improvements in growth rate and feed efficiency (Table 1). These studies, however, were conducted more than two decades ago, when disease pressures in pig farms were relatively greater than in today's facilities. With numerous improvements, such as multi-site pig production, nutrition, biosecurity, and overall pig husbandry practices in the last two decades, responses may not be as great. A more recent study ${ }^{3}$ on the use of in-feed antibiotics in modern production systems showed that such additives are still effective in improving growth in nursery pigs, although the magnitude of the response is less (Table 2). However, in finishing pigs, no improvement is noted. Many factors can affect the efficacy of antibiotic feed additives, including nutrition, management practices, and health status. When these factors are optimal, less or almost no response to antibiotics can be expected, especially with excellent sanitation practices and lack of bacterial disease pressure. The data on feeding antimicrobials in sow diets, however, is much more limited than that in growing pigs. Antibiotics in sow diets may improve reproductive performance in herds with a high incidence of reproductive problems due to greater disease challenge. ${ }^{4,5}$ Thus, herds experiencing problems with conception rates and litter size associated with bacterial infections may benefit from the addition of antibiotics to sow diets. Chlortetracycline and oxytetracycline, the two in-feed antibiotics approved for use in sow diets, are indicated to reduce the incidence of abortion due to Leptospira interrogans serovars and reduce shedding of these organisms. However, routine feeding of antibiotics to the breeding herd is discouraged.
Use of in-feed antibiotics in pigs is regulated by the Food and Drug Administration and they must be used only as approved.

No extra-label usage is allowed for in-feed antibiotics.

The best responses in growth performance are seen in nursery pigs.

Magnitude of responses may differ depending on herdhealth status and sanitation.

Concerns are increasing about the negative consequences of antibiotic use in food animals.

\section{Choosing the proper antibiotic}

When the antibiotic appropriate for a specific herd is selected, a number of important things must be considered, for example, the disease organisms present in the herd. Certain antibiotics may be more efficacious in treating respiratory problems, while others may be more effective against enteric pathogens. Stage of production and withdrawal period also will determine the specific antibiotic of choice. While in-feed antibiotic use is most prevalent in nursery diets, it is sometimes necessary to use antibiotics in grow-finish diets, eg, during outbreaks of bacterial disease. Observing the proper withdrawal time for an in-feed antibiotic is important to avoid residues in the meat. Improper consideration of withdrawal time may result in delays in marketing pigs. The product also must be approved for use in swine, as no extra-label usage is allowed for in-feed antimicrobials. Ultimately, choosing the proper in-feed

Table 1: Effectiveness of in-feed antibiotics on production responses in pigs*

Parameter Control Antibiotic Difference (\%) Starter phase (15 to $55 \mathrm{lb}$ )

$\begin{array}{llll}\text { ADG (lb) } \quad 0.86 & 0.99 & 16.4\end{array}$

$\begin{array}{llll}F: G & 2.28 & 2.13 & 6.9\end{array}$

Grower phase (37 to $108 \mathrm{lb}$ )

$\begin{array}{llll}\text { ADG (lb) } & 1.30 & 1.45 & 10.6 \\ \text { F:G } & 2.91 & 2.78 & 4.5\end{array}$

Grow-finish phase (53 to $196 \mathrm{lb}$ )

$\begin{array}{llll}\text { ADG (lb) } & 1.52 & 1.59 & 4.2 \\ \text { F:G } & 3.30 & 3.23 & 2.2\end{array}$

* Adapted from Cromwell $(2001)^{2}$ as adapted from Hays VW (Effectiveness of Feed Additive Usage of Antibacterial Agents in Swine and Poultry Production. Washington, DC: Office of Technology Assessment, US Congress; 1977) and Zimmerman DR [Role of subtherapeutic antimicrobials in animal production. J Anim Sci. 1986;62(Suppl3):6]. Data from 453,298 , and 443 experiments, involving 13,632, 5783, and 13,140 pigs for the three phases, respectively.

$A D G=$ average daily gain; $F: G=$ feed-to-gain ratio. 
Table 2: Effectiveness of in-feed antibiotics in nursery and grow-finish pigs reared in modern production systems*

\begin{tabular}{lcc|}
\hline Parameter & Control & Antibiotic $\dagger$ \\
\hline Nursery phase & & \\
\hline ADG (Ib) & $0.96 \dagger$ & $1.01 \dagger$ \\
F:G & 1.44 & 1.42 \\
\hline Grow-finish phase & & \\
\hline ADG (Ib) & 1.72 & 1.72 \\
F:G & 2.90 & 2.90 \\
\hline
\end{tabular}

* Adapted from Dritz et al, 2002. ${ }^{3}$ Data from five and four experiments, involving 3648 and 2660 pigs, for the nursery and grow-finish phases, respectively.

$\dagger$ ADG was greater (5.0\% difference) in nursery pigs treated with antibiotics than in controls (ANOVA; $P<.05$ )

$A D G=$ average daily gain; $F: G=$ feed-to-gain ratio.

antibiotic depends on the benefit in production efficiency compared to cost and risk of residue.

\section{Proper use of in-feed antibiotics}

While most in-feed antibiotics are available without veterinary supervision, they should not be used indiscriminately. They should be used only for purposes specified on the labels. A good reference for the list of drugs that can be used as feed additives is the Feed Additive Compendium, ${ }^{6}$ which is updated regularly to provide upto-date information and provides guidelines on the proper use of antibiotics in feed. Each country has its own regulatory policies regarding use of feed additives in pigs. Thus, the recommendations in this fact sheet may not apply outside of the United States. It is, therefore, important for US producers to be aware of which antibiotics are forbidden in countries that import pork from the United States.

\section{Which antibiotics are approved for use as feed addi- tives in pig diets in the United States?}

Antibiotics and combinations approved for use in swine diets, including withdrawal times, are listed in Table 3. Florfenicol and tilmicosin, which are classified as Veterinary Feed Directive (VFD) drugs, are also included in the list. Veterinary Feed Directive drugs can be used only under the order and professional supervision of an appropriately licensed veterinarian. ${ }^{7}$ Before a VFD drug can be used, the producer must first contact the veterinarian to diagnose and treat the existing health problem. A VFD order can be written only by a veterinarian for drugs that are approved for that swine category and under a valid client-patient relationship. ${ }^{7}$ This is accomplished by filling out a form in a format approved by the Food and Drug Administration Center for Veterinary Medicine. All pertinent information must be provided by the veterinarian. The veterinarian, producer, and feed miller must all follow the responsibilities outlined by the Food and Drug Administration Center for Veterinary Medicine when using VFD drugs. Issued VFDs for florfenicol and tilmicosin have an expiration period of 90 days.

\section{Summary}

Increased productivity, efficiency, and profitability are the goals of every swine-production business. Antibiotics have been used in swine diets for several decades to improve growth performance, as well as to control and treat diseases. Because of the improvements made in housing, nutrition, production, and health-management practices over the years, the impact of antibiotics on growth performance may not be as large or as consistent in response as those observed during the early years of antibiotic use. In-feed antibiotics remain an effective tool in improving production efficiency, but are not a substitute for good production management. These products must be used properly and responsibly.

\section{References}

1. Gaskins HR, Collier CT, Anderson DB. Antibiotics as growth promotants: mode of action. Anim Biotechnol. 2002;13:29-42.

2. Cromwell GL. Antimicrobial and promicrobial agents. In: Lewis AJ, Southern LL, eds. Swine Nutrition. 2nd ed. Boca Raton, Florida: CRC Press LLC; 2001:401-426.

3. Dritz SS, Tokach MD, Goodband RD, Nelssen JL. Effects of administration of antimicrobials in feed on growth rate and feed efficiency of pigs in multisite production systems. JAVMA. 2002;220:1690-1695.

4. Cromwell GL. Why and how antibiotics are used in swine production. Anim Biotechnol. 2002;13:7-27.

5. Alexopoulos C, Fthenakis GC, Burriel A, Bourtzi-Hatzopoulou E, Kritas SK, Sbiraki A, Kyriakis SC. The effects of the periodical use of in-feed chlortetracycline on the reproductive performance of gilts and sows of a commercial pig farm with a history of clinical and subclinical viral and bacterial infections. Reprod Domest Anim. 2003;38:187-192.

6. Feedstuffs. Feed Additive Compendium. Minnetonka, Minnesota: Miller Publishing Co; 2008.

7. Animal Drugs@ FDA. US Food and Drug Administration Center for Veterinary Medicine Web site. Available at: http://www.accessdata.fda. gov/scripts/animaldrugsatfda/. Accessed 10 July 2009. 
Table 3: Withdrawal periods for FDA-approved in-feed antibiotics and combinations*

\begin{tabular}{|c|c|c|c|}
\hline Antibiotic & Indication & $\begin{array}{l}\text { Inclusion rate } \\
\text { (g/ton) }\end{array}$ & $\begin{array}{l}\text { Withdrawal } \\
\text { period (days) }\end{array}$ \\
\hline \multirow{3}{*}{$\begin{array}{l}\text { Bacitracin } \\
\text { methylene } \\
\text { disalicylate (BMD) }\end{array}$} & Increased ADG and feed efficiency & $10-30$ & 0 \\
\hline & Grow-finish: control of swine dysentery & 250 & 0 \\
\hline & Sows: control of clostridial enteritis in suckling piglets & 250 & 0 \\
\hline \multirow{2}{*}{$\begin{array}{l}\text { BMD }+ \\
\text { chlortetracycline } \\
\text { (CTC) }\end{array}$} & Increased ADG and feed efficiency & \multirow{2}{*}{$\begin{array}{l}\text { BMD: } 10-30 \\
\text { CTC: } 400 \dagger\end{array}$} & \multirow[b]{2}{*}{0} \\
\hline & $\begin{array}{c}\text { Treatment of bacterial enteritis and } \\
\text { bacterial pneumonia }\end{array}$ & & \\
\hline Bacitracin zinc & Increased ADG and feed efficiency & $10-50$ & 0 \\
\hline Bambermycin & Increased ADG and feed efficiency & $2-4$ & 0 \\
\hline \multirow{2}{*}{ Carbadox } & Increased ADG and feed efficiency & $10-25$ & 42 \\
\hline & Control of swine dysentery and salmonellosis & 50 & 42 \\
\hline \multirow{4}{*}{ CTC } & Increased ADG and feed efficiency & $10-50$ & $\mathrm{VW} \ddagger$ \\
\hline & Reduction of jowl abscesses & $50-100$ & $\mathrm{VW} \ddagger$ \\
\hline & Control of leptospirosis in sows & $400 \dagger$ & $\mathrm{VW} \ddagger$ \\
\hline & Control of proliferative enteropathies (ileitis) & $\begin{array}{l}\text { BW dosage: } \\
10 \mathrm{mg} / \mathrm{lb} / \mathrm{d} \dagger\end{array}$ & $\mathrm{VW} \ddagger$ \\
\hline $\begin{array}{l}\text { CTC + sulfathiazole } \\
\text { + penicillin }\end{array}$ & $\begin{array}{l}\text { Reduction of abscesses; treatment of bacterial } \\
\text { enteritis; maintenance of weight gain in the } \\
\text { presence of rhinitis }\end{array}$ & $\begin{array}{c}100 \text { CTC; } \\
100 \text { sulfa; } \\
50 \text { penicillin }\end{array}$ & 7 \\
\hline Florfenicolף & Control of bacterial respiratory disease & 182 & 13 \\
\hline \multirow{3}{*}{ Lincomycin } & Increased ADG and feed efficiency & 20 & 0 \\
\hline & Control of swine dysentery and ileitis & $40-100$ & 0 \\
\hline & Reduce severity of mycoplasmal pneumonia & 200 & 0 \\
\hline Neomycin & Treatment and control of bacterial enteritis & $\begin{array}{c}\text { BW dosage: } 10 \\
\mathrm{mg} / \mathrm{lb} / \mathrm{d} \text { for } 24-48 \mathrm{~h} \\
\text { beyond remission of } \\
\text { symptoms, } \leq 14 \\
\text { consecutive days }\end{array}$ & 3 \\
\hline \multirow{3}{*}{$\begin{array}{l}\text { Neomycin/oxytetra- } \\
\text { cyline }\end{array}$} & Increased ADG and feed efficiency & $10-50$ & 5 \\
\hline & $\begin{array}{c}\text { Treatment of bacterial enteritis and } \\
\text { bacterial pneumonia }\end{array}$ & $\begin{array}{c}\text { BW dosage: } \\
10 \mathrm{mg} / \mathrm{lb} / \mathrm{d}, 7-14 \mathrm{~d}\end{array}$ & 5 \\
\hline & Control and treatment of leptospirosis in breeders & $\begin{array}{c}\text { BW dosage: } \\
10 \mathrm{mg} / \mathrm{lb} / \mathrm{d}, 7-14 \mathrm{~d}\end{array}$ & 5 \\
\hline \multirow{3}{*}{ Oxytetracycline } & Increased ADG and feed efficiency & $10-50$ & 0 \\
\hline & $\begin{array}{c}\text { Treatment of bacterial enteritis and } \\
\text { bacterial pneumonia }\end{array}$ & $\begin{array}{c}\text { BW dosage: } \\
10 \mathrm{mg} / \mathrm{lb} / \mathrm{d}, 7-14 \mathrm{~d}\end{array}$ & 0 \\
\hline & Control of leptospirosis in sows & $\begin{array}{c}\text { BW dosage: } \\
10 \mathrm{mg} / \mathrm{lb} / \mathrm{d}, 7-14 \mathrm{~d}\end{array}$ & 0 \\
\hline $\begin{array}{l}\text { Oxytetracycline } \\
+ \text { carbadox }\end{array}$ & $\begin{array}{c}\text { Treatment of bacterial enteritis and } \\
\text { bacterial pneumonia }\end{array}$ & $\begin{array}{l}\text { 10-25 carbadox; } \\
\text { oxytetracycline BW } \\
\text { dosage: } 10 \mathrm{mg} / \mathrm{lb} / \mathrm{d}\end{array}$ & 42 \\
\hline $\begin{array}{l}\text { Oxytetracycline } \\
+ \text { neomycin }\end{array}$ & $\begin{array}{l}\text { Prevention or treatment of bacterial enteritis and } \\
\text { dysentery; maintenance of weight gain in the } \\
\text { presence of atrophic rhinitis }\end{array}$ & $\begin{array}{c}\text { 50-150 oxytetra- } \\
\text { cycline; neomycin } \\
\text { BW dosage: } 35-140 \\
\mathrm{mg} / \mathrm{lb} / \mathrm{d}\end{array}$ & 10 \\
\hline
\end{tabular}




\begin{tabular}{|c|c|c|c|}
\hline Antibiotic & Indication & Inclusion rate (g/ton) & $\begin{array}{l}\text { Withdrawal } \\
\text { period (days) }\end{array}$ \\
\hline \multirow{2}{*}{ Tiamulin } & Control of dysentery and ileitis & 35 & 2 \\
\hline & Treatment of swine dysentery & 200 & 7 \\
\hline Tiamulin + CTC & $\begin{array}{c}\text { Control of dysentery; treatment of bacterial enteritis } \\
\text { and bacterial pneumonia }\end{array}$ & $\begin{array}{c}35 \text { tiamulin }+400 \\
\text { CTC (BW dosage: } 10 \\
\mathrm{mg} / \mathrm{lb} / \mathrm{d} \text { ) }\end{array}$ & 2 \\
\hline Tilmicosinף & Control of bacterial respiratory disease & $181-363$ & 7 \\
\hline \multirow{5}{*}{ Tylosin } & Increased ADG and feed efficiency in finishers & $10-20$ & 0 \\
\hline & Increased ADG and feed efficiency in growers & $20-40$ & 0 \\
\hline & Increased ADG and feed efficiency in nursery pigs & $20-100$ & 0 \\
\hline & Control of swine dysentery & $40-100$ & 0 \\
\hline & Control of dysentery and ileitis & 100 & 0 \\
\hline \multirow{3}{*}{ Virginiamycin } & Increased ADG and feed efficiency & $5-10$ & 0 \\
\hline & Control of swine dysentery & 25 & 0 \\
\hline & Treatment of swine dysentery & 100 & 0 \\
\hline
\end{tabular}

* Sources: 2008 Feed Additive Compendium 6 and Food and Drug Administration Center for Veterinary Medicine ${ }^{7}$.

$\dagger$ Limitations: feed continuously for $\leq 14$ days at approximately $400 \mathrm{~g} /$ ton of feed, varying with body weight (BW) and feed consumption to provide $10 \mathrm{mg} / \mathrm{lb}$ BW/d.

$\ddagger$ Voluntary withdrawal to meet residue limits of certain export markets.

१ Veterinary Feed Directive drug. 